Acta vet. scand. $1970,11,577-585$.

From the State Veterinary Serum Laboratory, Copenhagen, Denmark.

\title{
STUDIES ON ERYSIPELOTHRIX INSIDIOSA S. RHUSIOPATHIAE*)
}

1. MORPHOLOGY, CULTURAL FEATURES, BIOCHEMICAL REACTIONS AND VIRULENCE

\author{
By \\ V. Nфrrung
}

According to Pasteur \& Thuillier (1883) E. insidiosa was discovered by Thuillier on March 15, 1882.

By means of inoculation of pigs with broth culture of this organism, Pasteur \& Thuillier obtained the characteristic clinical picture of swine erysipelas, thus showing that the organisms were the cause of the disease. However, Pasteur stated emphatically that the finding applied to certain breeds of pig only, which observation was later to have great significance in connection with vaccination against the disease.

In trying to date back the first cases in Denmark, Jensen wrote in 1892: "The oldest report of the disease originates supposedly from E. Viborg who, in a book on the management of the pig published in 1804, gave a detailed description of 'anthrax' in swine. Though he made no mention of the characteristic redness of the skin, there can be no doubt that the disease referred to was swine erysipelas."

As is known, distinction is made between the following clinical forms: acute swine erysipelas, diamond disease, endocarditis, arthritis, and dry gangrene.

The incubation period in artificial infection with strongly virulent $\mathbf{E}$. insidiosa is $\mathbf{1 -} \mathbf{- 3}$ days. It is difficult to state a definite incubation period in the natural infection.

*) The studies were financially supported by the Danish State Research Foundation (Statens almindelige Videnskabsfond). 
It is a fact that many clinically healthy pigs are carriers for shorter or longer periods, and Connell $\&$ Langford (1953) isolated the organisms from $30 \%$ of 639 apparently healthy pigs. The organisms were cultured from the tonsils in 115 cases; from tonsils and gall bladder in 29; from tonsils, gall bladder, and intestinal canal in 12; from tonsils and intestinal canal in 12; from gall bladder alone in 7; from gall bladder and intestinal canal in 6; and from the intestinal canal alone in 11 cases.

There was great seasonal variation, the majority of the positive cultures being found in the month of July and August.

As mentioned, the disease occurs in different clinical forms. How can the same organism cause so widely varying disease manifestations?

The same question was asked by Jensen i 1892 . He found 3 possible answers: 1) the route of infection, 2) breed and individual peculiarities, and 3 ) variations in the virulence of the bacterium.

Having confuted the first 2 possibilities, Jensen wrote: "There is therefore nothing left but to assume that it must be the varying degree of virulence of the bacillus, perhaps combined with greater or lesser individual receptivity, that determines the character of the disease and its mild or severe course (diamond disease or swine erysipelas)."

The aim of the present study was to elucidate the problem: do strains of E. insidiosa responsible for chronic forms of swine erysipelas possess any peculiar characteristics as regards morphology, cultural features, biochemistry, or virulence? Later studies will deal with possible differences in antigenic structure, and with the question whether the occurrence of the infection can be diminished or eliminated by vaccination.

\section{MATERIAL}

The material originated from the Cooperative Bacon Factory at Sor $\left.\phi^{\star}\right)$. It consisted of 808 unopened joints from pigs suspected of arthritis because of lameness, swelling of 1 or more joints, or affected (swollen, hyperaemic) regional lymph nodes.

E. insidiosa was isolated from 112 of the 808 specimens, either from joints or regional lymph nodes, or both. Table 1 shows the

*) The writer is indebted to the following colleagues for making the material available: K. O. Hansen, K. Haarbo, and the late Jens Chr. Sørensen. 
serial numbers, slaughter-house numbers, and supplier numbers of the strains examined.

The joints were either sent in to the laboratory immediately after slaughter, or, more frequently, deep-frozen at the slaughterhouse and sent in later.

\section{METHODS}

The unopened joint was examined by palpation and, after scorching, the joint cavity was opened by an about $1 \mathrm{~cm}$ long incision in the joint capsule. A small amount of synovial fluid was pipetted off and inoculated on $5 \%$ blood agar plates.

The joint was then opened completely, and after recording of possible patho-anatomical changes cultures were made from any area with such changes. If there were no changes, cultures were made from scrapings of the synovial capsule and the joint cartilage.

The plates were incubated at $37^{\circ} \mathrm{C}$ for 24 to $48 \mathrm{hrs}$., after which they were examined for suspect colonies by means of transmitted light and a magnifying glass. Subcultures of suspect colonies were made on blood agar plates, which were incubated at $37^{\circ} \mathrm{C}$ for $24 \mathrm{hrs}$. Gram-stained smears from subcultures were examined by microscopy, and if gram-positive, slender, short rods were found, $0.5 \mathrm{ml}$ of a suspension of a plate culture was inoculated intraperitoneally into mice.

Heart blood of mice that died within 2-4 days was inoculated on blood plates, which were incubated at $37^{\circ} \mathrm{C}$ for $24 \mathrm{hrs}$. From the plate cultures fermentation tubes were inoculated for determination of biochemical activity. These tubes were incubated at $37^{\circ} \mathrm{C}$ and inspected daily. Positive findings were recorded with a plus sign and a figure indicating the number of days that elapsed before the appearance of the positive reaction.

Two different media were used for examination for hydrogen sulphide. Originally, only $\mathrm{FeCl}_{2}$-gelatine was employed, but this medium was difficult to keep in solid form at moderately elevated temperatures, and was therefore replaced by iron agar. However, when it was found that a number of strains did not show formation of $\mathrm{H}_{2} \mathrm{~S}$ within 3 weeks, the medium described by Kemenes \& Kucsera (1967) was adopted. This medium, which is semi-fluid, consists of broth to which is added $1 \%$ glucose, $10 \%$ horse serum, $0.2 \%$ sodium thiosulphate, $0.04 \%$ lead acetate and $0.2 \%$ agar. 


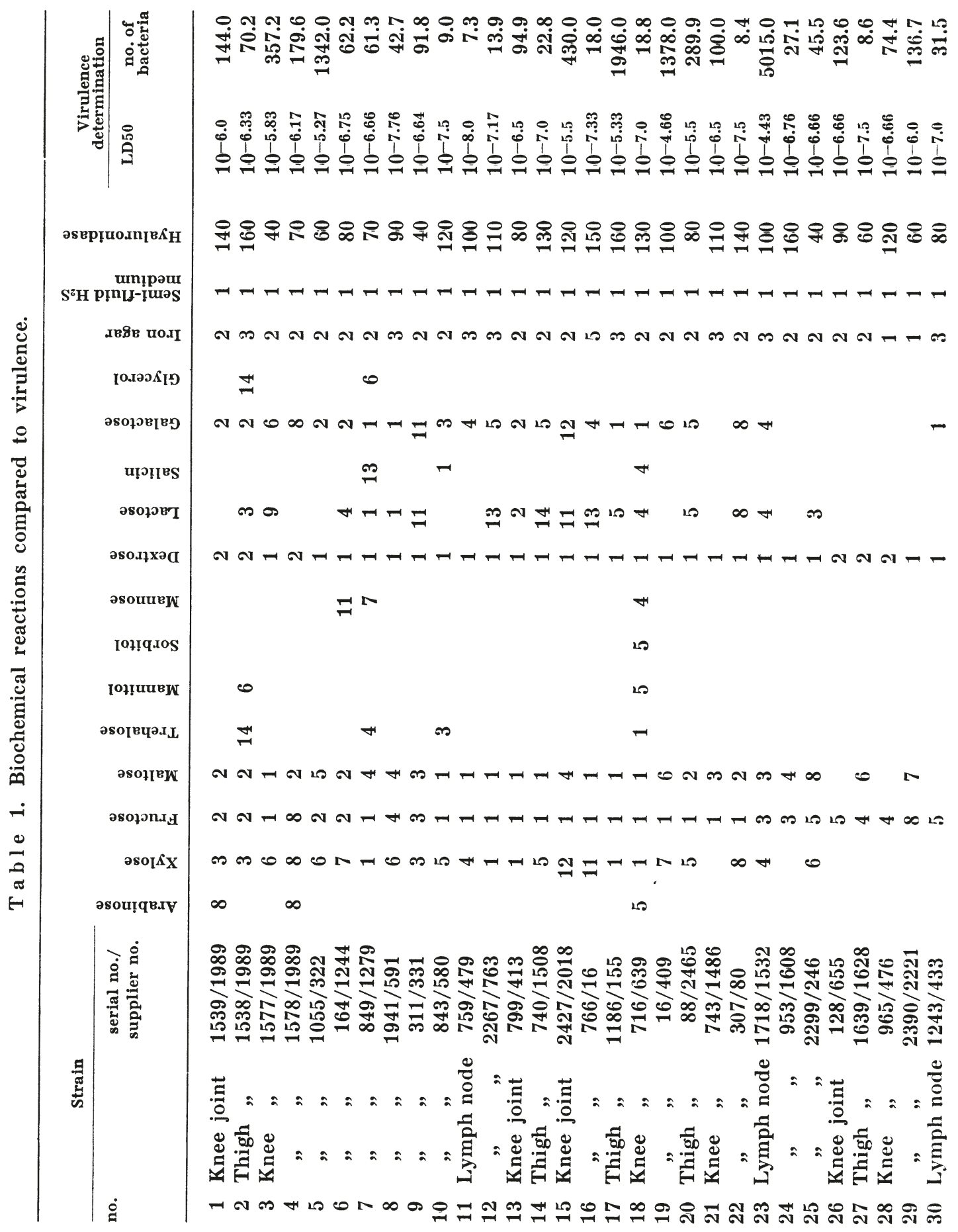




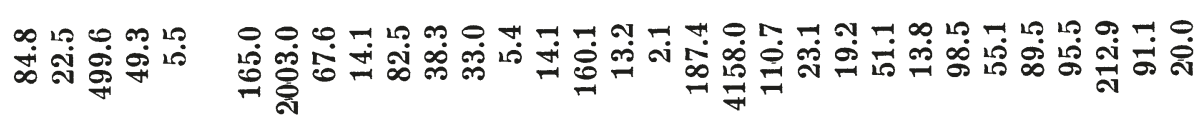

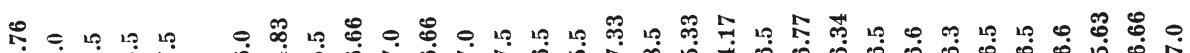
金金全全全

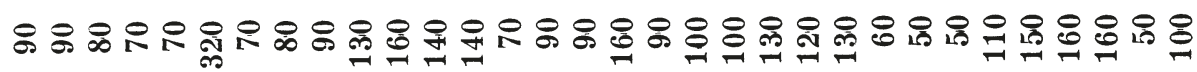

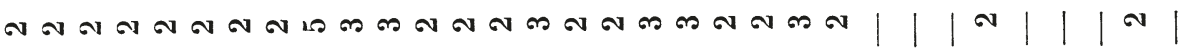

5

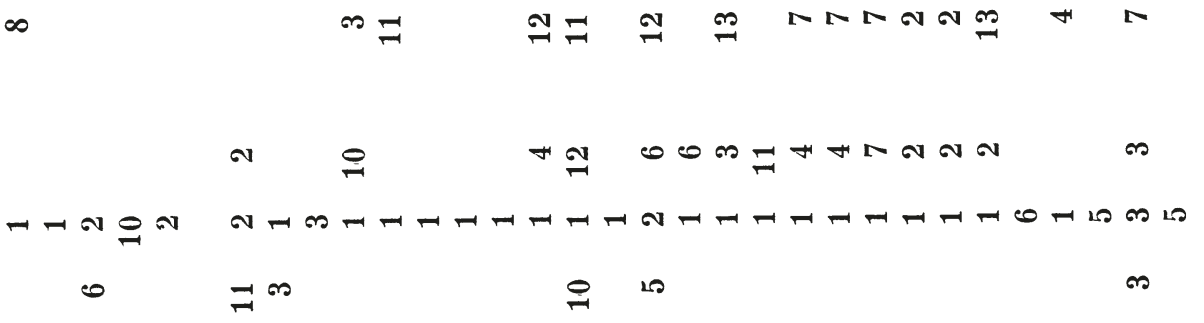

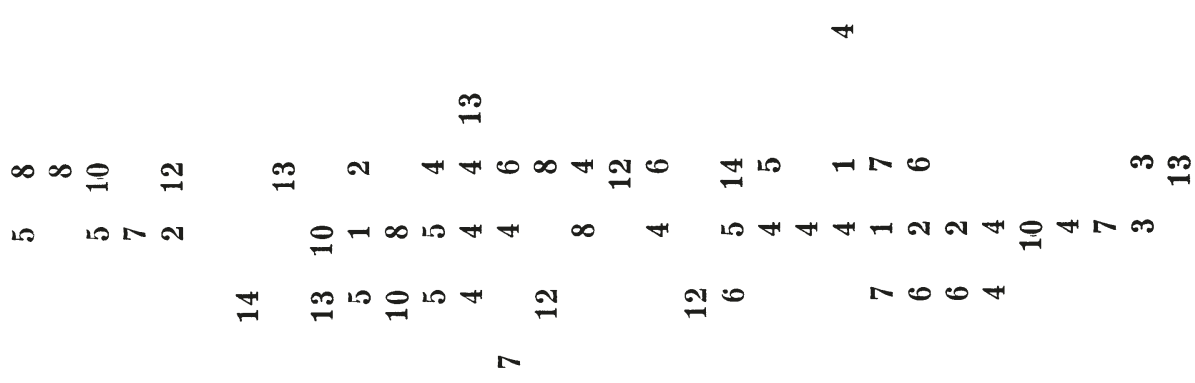

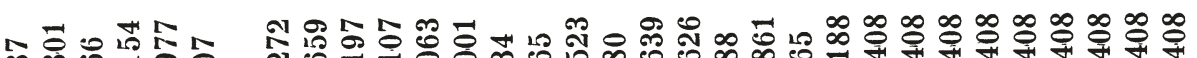

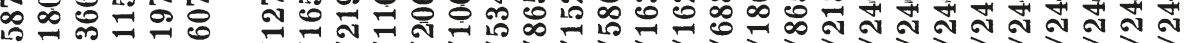
को

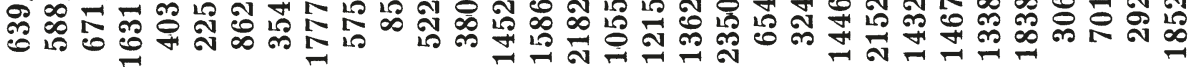

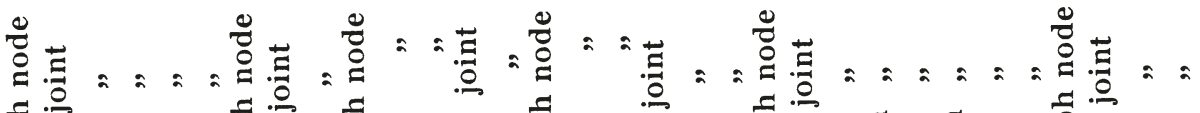

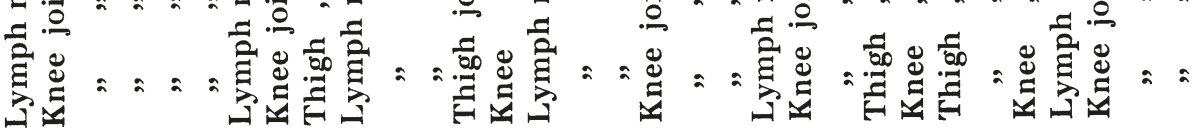

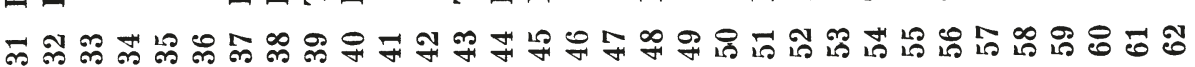

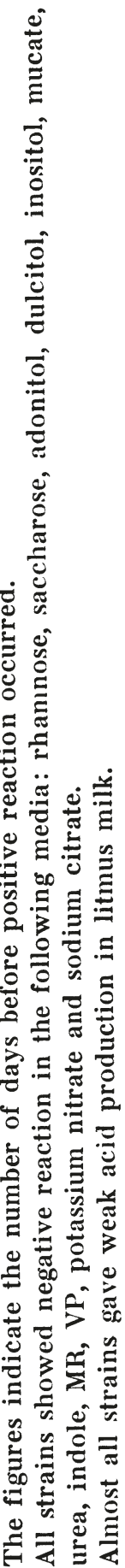


Determination of the virulence of E. insidiosa. Beef extract broth, $\mathrm{pH}$ 7.4, was inoculated with growth from a 24-hr.-old plate culture. After incubation at $37^{\circ} \mathrm{C}$ for $24 \mathrm{hrs}$., serial tenfold dilutions of the resulting culture were made in beef extract broth, and $0.5 \mathrm{ml}$ of each of the dilutions $10^{-1}$ to $10^{-10}$ injected i.p. into each of 4 mice for determination of LD50. Viable counts were made on dilutions $10^{-6}$ to $10^{-8}$ by inoculation of $0.1 \mathrm{ml}$ of each dilution on each of 5 blood agar plates.

LD50 was calculated according to the method described by Reed \& Muench (1938).

Virulence determination on pigs was performed by intracutaneous injection of $0.1 \mathrm{ml}$ of a $24-\mathrm{hr}$.-old broth culture, followed by measurements of temperature night and morning and daily recording of possible local reactions.

Determination of hyaluronidase. The method used was that described by Ewald (1957) with bovine synovial fluid as source of hyaluronic acid.

The titre of the hyaluronic acid was determined as the reciprocal value of the highest dilution that, when added dropwise to acid alcohol (96 $\mathrm{ml} 96 \%$ ethyl alcohol, $4 \mathrm{ml} 25 \%$ hydrochloric acid), gives a confluent drop. For determination of hyaluronidase in a strain of E. insidiosa a 24-hr.-old broth culture was adjusted to a density of about 500 mill. organisms per $\mathrm{ml}$, corresponding to no. 2 in Coleman's photo-nephelometric scale.

The culture was centrifuged for $30 \mathrm{~min}$. at 3000 r.p.m. and $0.25 \mathrm{ml}$ of each of a series of dilutions $(1: 10,1: 20,1: 30$, etc. up to $1: 160$, and $1: 320$ ) of the supernatant fluid in physiological saline was mixed with $0.25 \mathrm{ml}$ of a solution of synovial fluid with a hyaluronic acid concentration 3 times that found as endpoint in the above-mentioned titration.

After $1 \mathrm{hr}$. in water bath at $37^{\circ} \mathrm{C} 0.1 \mathrm{ml}$ congo red $(0.5 \%)$ was added, and the tubes were shaken vigorously. After 5 min. at room temperature titration was performed.

The highest concentration of culture fluid in which coagulation would occur when a drop was added to acid alcohol would indicate the hyaluronidase titre limit.

\section{RESULTS AND DISCUSSION}

The strains of E. insidiosa examined appeared as grampositive rods, the length of which varied with the moistness of the medium. On very moist medium, e.g. serum agar, the organisms often formed long threads. 
T a b l e 2. Virulence tests on pigs.

\begin{tabular}{|c|c|c|c|c|c|c|c|c|c|}
\hline \multirow[b]{2}{*}{$\begin{array}{l}\text { Pig } \\
\text { no. }\end{array}$} & \multirow[b]{2}{*}{$\begin{array}{c}\text { Strain } \\
\text { no. }\end{array}$} & \multicolumn{7}{|c|}{ Temperature } & \multirow[b]{2}{*}{$\begin{array}{l}\text { Skin reaction } \\
3 \text { days after } \\
\text { inoculation }\end{array}$} \\
\hline & & $\begin{array}{l}\text { Inoculated } \\
10 \text { a.m. } \\
\text { Dec. } 9\end{array}$ & Dec. 10 & Dec.11 & Dec.12 & Dec.13 & Dec.14 & Dec.15 & \\
\hline \multirow[t]{2}{*}{1} & 36 & & 39.0 & 39.2 & 39.2 & 39.0 & 39.2 & 38.5 & \\
\hline & & $\overline{39.1}$ & 39.0 & 38.8 & 38.8 & 38.6 & 38.7 & 38.5 & 一 \\
\hline \multirow[t]{2}{*}{2} & 42 & & 38.5 & 38.5 & 39.7 & 39.6 & 39.5 & & \\
\hline & & & $\overline{38.8}$ & $\overline{38.6}$ & $\overline{39.1}$ & $\overline{39.2}$ & $\overline{39.3}$ & & ++ \\
\hline \multirow[t]{2}{*}{3} & 55 & & 39.6 & 40.3 & 39.8 & 39.2 & 38.7 & 38.8 & \\
\hline & & 39.0 & 39.5 & 40.0 & 39.9 & 39.5 & 39.8 & 39.0 & ++ \\
\hline \multirow[t]{2}{*}{4} & 57 & & 39.3 & 39.8 & 39.6 & 39.7 & 39.0 & 39.0 & \\
\hline & & 38.9 & 39.5 & 40.0 & 39.2 & 39.9 & 39.0 & 39.2 & + \\
\hline \multirow[t]{2}{*}{5} & 58 & & 39.5 & 40.4 & 40.5 & 40.7 & 38.5 & 38.9 & \\
\hline & & 39.0 & 39.0 & 40.2 & 40.1 & 41.5 & 39.1 & 39.0 & +++ \\
\hline \multirow[t]{2}{*}{6} & 60 & & 38.8 & 40.1 & 40.0 & 40.4 & 39.8 & 39.6 & \\
\hline & & $\overline{38.5}$ & $\overline{39.8}$ & $\overline{40.1}$ & $\overline{39.8}$ & $\overline{40.0}$ & $\overline{39.8}$ & $\overline{39.5}$ & ++ \\
\hline \multirow[t]{2}{*}{7} & 62 & & 40.1 & 39.0 & 39.1 & 40.3 & 40.4 & 38.6 & \\
\hline & & $\overline{38.4}$ & $\overline{40.3}$ & 38.8 & $\overline{39.3}$ & $\overline{40.0}$ & $\overline{39.6}$ & $\overline{39.5}$ & ++ \\
\hline \multirow{2}{*}{8} & Swedish & & 39.9 & 39.8 & 39.8 & 40.4 & 40.6 & 39.5 & \\
\hline & $\mathrm{R} / 9$ & $\overline{39.5}$ & $\overline{39.8}$ & $\overline{39.1}$ & $\overline{39.0}$ & $\overline{40.2}$ & $\overline{39.7}$ & $\overline{39.0}$ & +++ \\
\hline & Morn & peratu & & & \multirow{2}{*}{\multicolumn{5}{|c|}{$\begin{array}{l}+,++ \text { and }+++ \text { indicate the } \\
\text { reaction of the site of injection: } \\
\text { slight redness, severe redness, very } \\
\text { severe redness and swelling. }\end{array}$}} \\
\hline & Eveni & perat & & & & & & & \\
\hline
\end{tabular}

Table 1 shows the results of the biochemical tests, the virulence determination, and the viable counts.

Biochemically 60 strains were largely similar, all showing a limited biochemical activity. Two strains were clearly different from the others. One (no. 36) showed the lowest degree of biochemical activity, forming $\mathrm{H}_{2} \mathrm{~S}$ only. The other (no. 18) showed the highest degree of activity.

All strains formed $\mathrm{H}_{2} \mathrm{~S}$ in semi-fluid $\mathrm{H}_{2} \mathrm{~S}$ medium, while 7 showed no demonstrable amounts in Fe agar. Reports in the literature of a frequent occurrence of strains of E.insidiosa which do not form $\mathrm{H}_{2} \mathrm{~S}$ may be ascribable to the use of a not 
sufficiently sensitive medium. Nielsen (1966) found that 3 out of 15 strains examined were $\mathrm{H}_{2} \mathrm{~S}$ negative in the medium employed (iron agar).

Virulence determination on mice proved that 61 strains were strongly virulent, the LD50 being from $0.5 \times 10^{-4.17}$ to $0.5 \times 10^{-8.5}$. One strain (no. 36 which was also rather inactive biochemically) was avirulent, intraperitoneal injection of $0.5 \mathrm{ml}$ of a 24 -hr.-old broth culture causing no sign of disease in the mice during the observation period (14 days). This result was rather surprising, since it might have been expected that chronic infections would be caused by weakly virulent organisms.

Virulence determination on pigs was carried out with 7 strains isolated from joints of pigs with arthritis, and with a strongly virulent Swedish strain of E. insidiosa (R/9). As appears from Table 2, 6 of the arthritis strains gave moderate to strong local reactions and/or rise of temperature, while 1 strain was avirulent. The avirulent strain (no. 36) was the same as the one shown to be avirulent for mice.

All strains were examined for production of hyaluronidase (Table 1). Unexpectedly, the highest hyaluronidase content was not found in the strongly virulent strains, but in the strain (no. 36) that was avirulent for mice and pigs.

\section{CONCLUSION}

In the present investigations, strains of E. insidiosa isolated from pigs with chronic infection (in this case arthritis) were found not to be different from other strains of this species as regards morphology, cultural features, biochemical reactions and virulence.

\section{REFERENCES}

Connell, R. \& E. V. Langford: Studies of swine erysipelas. V. Presence of Erysipelothrix rhusiopathiae in apparently healthy pigs. Canad. J. comp. Med. 1953, 17, 448-453.

Ewald, F. W.: Das Hyaluronidasebildungsvermögen von Rotlaufbakterien). (The ability of E. rhusiopathiae to form hyaluronidase). Mh. Tierheilk. 1957, 9, 333-341.

Jensen, C. O.: Om Knuderosen, $t \varnothing r$ Hudbrand og R $\varnothing$ dsyge. (Diamond disease, dry gangrene and erysipelas). Beretn. Fors $\emptyset$ gslab. (Kbh.) 25, 1892, 26-56.

Kemenes, F. \& Gy. Kucsera: Fin neues Verfahren zum Nachweis der $\mathrm{H}_{2} \mathrm{~S}$-Produktion der Schweinerotlaufbakterien. (A new method to show $\mathrm{H}_{2} \mathrm{~S}$ production in erysipelothrix rhusiopathiae). Zbl. Vet.-Med. B, 1967, 14, 402-407. 
Nielsen, $N$. C.: Kronisk produktiv og deformerende polyarthritis hos grise. II. Yatologisk-anatomiske og bakteriologiske unders $\varnothing$ gelser. (Chronic proliferative and deformating polyarthritis in pigs. II. Pathological and bacteriological investigations). Nord. Vet.-Med. 1966, 18, 385-416.

Pasteur, L. \& L. Thuillier: La vaccination du rouget des porcs à láide du virus mortel atténué de cette maladie. (Vaccination of pigs against erysipelas by means of a virulent attenuated strain of Erysipelothrix rhusiopathiae). C. R. Acad. Sci. (Paris) 1883, 97, $1163-1169$.

Reed, L. J. \& H. Muench: A simple method of estimating fifty per cent endpoints. Amer. J. Hyg. 1938, 27, 493-497.

\section{SUMMARY}

Sixty-two E.insidiosa strains isolated from joints or regional lymph nodes of pigs were examined from the point of view of morphology, cultural aspects, biochemical activity and virulence. All the strains consisted of gram-positive, short rods, which were similar on solid and fluid media. All strains formed $\mathrm{H}_{2} \mathrm{~S}$. Otherwise the biochemical activity was rather low except in 1 strain (no. 18), which was very active. One strain (no. 36) was rather inactive, since it showed no other activity than $\mathrm{H}_{2} \mathrm{~S}$ formation. This latter strain was the only one that was avirulent for mice. The rest of the strains (61) were strongly virulent for mice (LD50 $0.5 \times 10^{-4.17}$ to $0.5 \times 10^{-8.5}$ ).

of 7 strains examined for virulence for pigs by intracutaneous injection of $0.1 \mathrm{ml}$ broth culture, 6 were virulent. The $7 \mathrm{th}$, which was avirulent, was the one that was also avirulent for mice.

\section{SAMMENDRAG}

Unders $\phi$ gelser over Erysipelothrix insidiosa s. rhusiopathiae.

1. Morfologi, kulturelle forhold, biokemi og resistens.

Toogtres rødsygestammer dyrket fra led eller lymfekirtler af grise er unders $\emptyset$ gt med hensyn til morfologi, kulturelle forhold, biokemisk aktivitet og virulens.

Alle stammer var gram-positive korte stave, som ikke adskilte sig fra hinanden ved dyrkning på fast og i flydende substrat.

Alle stammer dannede $\mathrm{H}_{2} \mathrm{~S}$.

Den biokemiske aktivitet var ret beskeden med undtagelse af én stamme (no. 18), der var meget aktiv.

En stamme (no. 36) var relativt inaktiv, idet den ikke viste biokemisk aktivitet udover at danne $\mathrm{H}_{2} \mathrm{~S}$.

Denne stamme var den eneste, der var avirulent for mus. De $\emptyset$ vrige 61 stammer var stærkt musepatogene (LD50 $0,5 \times 10^{-4,17}$ til $0,5 \times 10^{-8,5)}$.

Af 7 stammer, hvis virulens for grise blev unders $\varnothing$ gt ved intrakutan injektion af $0,1 \mathrm{ml}$ bouillonkultur, var 6 virulente. Den 7., som var avirulent, var den samme stamme, som var avirulent for mus. 